\title{
Irrigation as an alternative to reduce damages caused by defoliation of sweet corn
}

\author{
Osvaldir F Santos ${ }^{1}$; Sebastião F Lima²; Gabriel Luiz Piati²; Gustavo R Barzotto²; Ricardo Gava² \\ 'Universidade Estadual Paulista "Júlio de Mesquita Filho" (UNESP), Botucatu-SP, Brazil; osvaldir.feliciano@gmail.com; ${ }^{2}$ Universidade \\ Federal de Mato Grosso do Sul (UFMS), Chapadão do Sul-MS, Brazil; sebastiao.lima@ufms.br; gabrielpiati@hotmail.com; gustavo. \\ barzotto@hotmail.com; ricardo.gava@ufms.br
}

\begin{abstract}
Reduction of leaf area significantly affects maize productivity, due to its low plasticity. Thus, appropriate water application can minimize this problem, considering that under favorable water conditions the plant would express its maximum production potential. The aim of this study was to evaluate the influence of irrigation on the productive performance of sweet corn submitted to different defoliation levels at the beginning of crop cycle. The experimental design was a randomized block design, arranged in split plot scheme; plots consisting of four water depths $[50,75,100$ and $125 \%$ of crop evapotranspiration (ETc)] and the subplots consisted of three defoliation levels [ $0 \%$ (control); $35 \%$ (removal of four fully expanded leaves), $100 \%$ (total removal of leaves, shoot section)], with three replicates. The use of irrigation has a positive influence on recovery of damages caused by defoliation at the initial development stages of sweet corn, and the success of irrigation management, as a strategy to mitigate damages caused by defoliation, depends on the level of the lost leaf area and the amount of water used.
\end{abstract}

Keywords: Zea mays, water availability, leaf area, grain yield.

\section{RESUMO}

Irrigação como alternativa para reduzir os prejuízos ocasionados por desfolha do milho doce

A redução da área foliar afeta drasticamente a produtividade do milho, em função da sua baixa plasticidade. Assim, aplicação adequada de água pode minimizar este problema, tendo em vista que, em condições hídricas favoráveis, a planta expressaria seu potencial máximo de produção. Avaliou-se a influência da irrigação no desempenho produtivo do milho doce submetido a diferentes níveis de desfolha no início do ciclo da cultura. O delineamento experimental foi em blocos casualizados em esquema de parcelas subdivididas, tendo nas parcelas quatro lâminas de irrigação [50, 75, 100 e $125 \%$ da evapotranspiração da cultura (ETc)] e nas subparcelas três níveis de desfolha [0\% (testemunha); 35\% (remoção de quatro folhas completamente expandidas); 100\% (remoção total das folhas, secção da parte aérea)], com três repetições. O emprego de irrigação apresenta influência positiva na recuperação de danos ocasionados por desfolha em estágios iniciais de desenvolvimento do milho doce, sendo que, o sucesso no manejo da irrigação como estratégia para atenuar os prejuízos ocasionados pela desfolha, depende do nível da área foliar perdida e da lâmina de água empregada.

Palavras-chave: Zea mays, disponibilidade hídrica, área foliar, rendimento de grãos.

\section{Received on March 23, 2017; accepted on February 19, 2018}

$S_{8}$ weet corn (Zea mays, saccharata group) is a special kind of maize and dedicated exclusively for human consumption, used mainly as green corn, both in natura and processed by vegetable canning industries (Oliveira Júnior et al., 2006). Its phenology is quite similar to conventional corn; however, according to Kwiatkowski \& Clemente (2007), a genetic mutation gives the grains a sweet taste, since these recessive genes prevent conversion of sucrose to starch.

Despite the high productive potential, maize is sensitive to water stress, which contributes to reduce its leaf area, since maize presents low vegetative plasticity (Sangoi et al., 2014). In relation to leaf structure, damages caused may reflect negatively in the growth of the whole plant, since leaves respond to the main source of photoassimilates, which are the most important photosynthesizing organs of maize (Karam et al., 2010).

This effect is potentiated when it occurs at more advanced stages of crop cycle (Fancelli \& Dourado Neto, 2004). However, maize productive potential is defined around V4 and V5 vegetative stages, when plants present four and five expanded leaves, respectively, in relation to floral differentiation and of all leaves (Ritchie et al., 1993).

Inappropriate irrigation management can cause stress during beginning of the crop cycle even worse, due to biotic and abiotic factors such as attack of bed bugs, caterpillars or even hail. According to Magalhães \& Durães (2006), at this stage, growth point, which is below the soil surface, is quite affected not only by temperature but 
also by water availability, considering that excess moisture affects plant development, and can even cause plant death.

Nevertheless, mechanisms through which nutrients reach roots, mass flow and diffusion, are directly related to soil water availability (Taiz \& Zeiger, 2013), thus, appropriate irrigation management can mitigate stress caused by defoliation, considering that in favorable water conditions plant would express its maximum production potential.

Thus, the aim of this work was to evaluate the influence of irrigation on the productive performance of sweet corn submitted to different defoliation levels at beginning of the crop cycle.

\section{MATERIAL AND METHODS}

The experiment was carried out at Federal University of Mato Grosso do Sul, Chapadão do Sul campus (1847'39'S, 52³7'22'W, 820 m altitude). Climate of the region is humid tropical (Peel et al., 2007), maximum and minimum temperatures 33.6 and $7.1^{\circ} \mathrm{C}$, respectively; maximum and minimum relative humidity is 95 and $24 \%$ and rainfall of $548.65 \mathrm{~mm}$ and crop evapotranspiration around $3.71 \mathrm{~mm}$ day $^{-1}$ during the experiment. These data were collected at meteorological station of the National Institute of Meteorology (INMET) installed at a distance of 3.84 $\mathrm{km}$ and rainfall data were collected in the experimental area because of its variability.

Soil was classified as typic distrophic Red Latosol, clayey texture (Embrapa, 2013), density of $1.2 \mathrm{~g} \mathrm{dm}^{-3}$ and water contents equivalent to field capacity and permanent wilting point of 0.265 and $0.186 \mathrm{dm}^{3} \mathrm{dm}^{-3}$, respectively. Chemical properties in the $0-20 \mathrm{~cm}$ layer were: $9.0 \mathrm{mg} \mathrm{dm}^{-3}$ of P (resin); $33.5 \mathrm{~g} \mathrm{dm}^{-3}$ of organic matter; $4.9 \mathrm{pH}\left(\mathrm{CaCl}_{2}\right) ; \mathrm{K}^{+}$, $\mathrm{Ca}^{2+}, \mathrm{Mg}^{+2}$ and $\mathrm{H}+\mathrm{Al}=0.07 ; 2.40 ; 0.90$

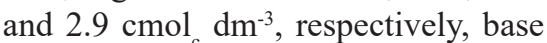
saturation, $53.7 \%$.

Soil preparation consisted of plowing and, then, harrowing. Acidity was corrected and sowing fertilization was performed based on soil chemical analysis, according to recommendation for maize crop (Souza \& Lobato, 2004). Nitrogen topdressing was split and applied on V4 and V8 vegetative stages, using urea as nitrogen source $(45 \% \mathrm{~N})$, totalizing $150 \mathrm{~kg} \mathrm{ha}^{-1}$ of $\mathrm{N}$.

The experiment was carried out in a split plot scheme, with four irrigation depths [50, 75, 100 and 125\% crop evapotranspiration (ETc)] and at subplots, three defoliation levels [0\% (control); 35\% (with the removal of four fully expanded leaves) and 100\% (total removal of leaves, shoot section)], with three replicates. Defoliation was done manually, leaf blade has been removed from its base, according to each treatment, in V4 vegetative stage (four expanded leaves) at 25 days after emergence (DAE). Plots were $4 \mathrm{~m}$ length ( $1.0 \mathrm{~m}$ border) and $2.25 \mathrm{~m}$ width ( $0.9 \mathrm{~m}$ border), resulting in $9 \mathrm{~m}^{2}$ total area and $4.5 \mathrm{~m}^{2}$ useful area.

Sowing was performed on February 13 , 2016, spacing $0.45 \mathrm{~m}$ between rows and $0.3 \mathrm{~m}$ between plants, adopting density of 75.000 seeds $\mathrm{ha}^{-1}$. Simple hybrid Tropical Plus (Syngenta), was used. This hybrid presents from 90 to 110 day cycle, light yellow grain color, thin pericarp, sweet flavor and resistance to main diseases.

Seeds were treated by the processing industry using Captan (120 g i.a./100 $\mathrm{kg}$ seeds), Carboxin and Thiram (188 g i.a./100 kg seeds), Pirimiphos-Methyl (0.6 g i.a./100 kg seeds), Deltamethrin (0.1g i.a./100 kg seeds) and Fludioxinil and Metalaxyl-M (3.75 g i.a./100 kg seeds). During the experiment, phytosanitary treatments were: two applications of insecticide Methomyl (129 g i.a./ha) and one application of herbicides Tembotrione (100.8 g i.a./ha) and Atrazine (1.5 kg i.a./ha).

Water was supplied through drip irrigation system, with 1-day fixed irrigation shift, consisting of 20-meter high reservoir, 50- $\mathrm{mm}$ diameter PVC pipeline, main pipes 32-mm diameter PVC and 16-mm inner diameter dripper lateral lines (Petroisa drip hose), using an emitter flow rate of $1.29 \mathrm{~L} \mathrm{~h}^{-1}$, under $98 \mathrm{kPa}$ pressure. Water was distributed uniformly through irrigation system according to Christiansen Uniformity Coefficient (CUC) equal to $96.2 \%$, one dripping lateral line for each row of plants, 0.20-m spacing between emitters, establishing a uniform wet band along plant rows.

Actual irrigation required for 100\% crop evapotranspiration was performed in relation to climate parameters, plant and soil characteristics, representing actual water required in the system (Eq. 1):

$\mathrm{IRN}_{\mathrm{LOC}}=\sum_{\text {dia }_{1}}^{i} E T_{0} x K_{C} x K_{S} x K_{L}-P_{E}$ (1)

in which

$\mathrm{IRN}_{\text {LOC }}=$ actual irrigation required in localized systems $(\mathrm{mm})$; ETo= reference evapotranspiration $\left(\mathrm{mm} \mathrm{day} \mathrm{da}^{-1}\right) ; \mathrm{K}_{\mathrm{C}}=$ crop coefficient (dimensionless); $\mathrm{K}_{\mathrm{S}}=$ soil moisture coefficient (dimensionless); $\mathrm{K}_{\mathrm{L}}=$ location coefficient (dimensionless); and $\mathrm{P}_{\mathrm{E}}=$ effective rainfall during the period $(\mathrm{mm})$.

IRN value was corrected in relation to irrigation application efficiency, defining the total actual irrigation (ITN) (Eq. 2):

$$
\mathrm{ITN}=\frac{I R N_{L O C}}{E a}
$$

in which:

ITN $=$ total irrigation required $(\mathrm{mm})$; $\mathrm{IRN}_{\mathrm{LOC}}=$ actual irrigation required in localized systems $(\mathrm{mm})$; and $\mathrm{Ea}=$ water application efficiency (decimal), based on CUC.

Soil moisture coefficient (Ks) (Bernardo et al., 2008) and location coefficient $\left(\mathrm{K}_{\mathrm{L}}\right)$ (Keller \& Bliesner, 1990) were calculated according to their respective methodologies.

Penman Monteith-FAO56 methodology was used to estimate ETc (Allen et al., 1998) using Crop coefficient (Kc) 0.8 and 1.2 for stages I and III, respectively. For stage II, linear weighting between end of stage I and beginning of stage III was used. Stages I, II and III lasted 16, 24 and 30 days, respectively, and stage IV from $70^{\circ}$ sowing day up to harvest.

Corn was harvested and phytotechnical characteristics were evaluated at 80 days after emergence (DAE), when the plant reached phenological phase, R3, (the plant showed milky grains).The evaluated 
traits were plant length (distance from soil level up to the last fully expanded leaf insertion), cob insertion (distance from soil level up to the first viable cob insertion), plant leaf area [measured with a leaf area meter CI-203 Laser area meter (CID Bio-Sience)]. All fully expanded leaves were measured; productivity, determined by the harvest of all viable spikes in the useful area of each experimental unit. Then, these spikes were weighed $\left(\mathrm{kg} \mathrm{plot}^{-1}\right)$, being this value extrapolated to $t \mathrm{ha}^{-}$ ${ }^{1}$, EUA (water use efficiency, in $\mathrm{kg}$ $\mathrm{m}^{-3}$, determined by the ratio between productivity and quantity of water used during crop cycle).

Data were submitted to analysis of variance, F test. Qualitative factor (defoliation levels) was evaluated through average comparison, according to Tukey, $5 \%$ probability, whenever any significant difference was verified. For quantitative factor, models were chosen based on significance of regression coefficients.

\section{RESULTS AND DISCUSSION}

Average values of irrigation water depths applied to the treatments designed to replace 50, 75, 100 and $125 \%$ ETc were $105.7 ; 158.5 ; 211.5$ and $264.2 \mathrm{~mm}$, respectively. Overall, the authors could verify a significant interaction between defoliation levels and water depths for all evaluated parameters except for water use efficiency.

An increase of water depth resulted in increase of plant length at 35 and $100 \%$ defoliation levels (Figure 1A); In no-defoliation treatment, sweet corn reached maximum height of $175.0 \mathrm{~cm}$ of water depth with replacement of $98.4 \%$ $\mathrm{ETc}$, and 35 and $100 \%$, leaf area removal treatments, the authors noticed higher length values, with water depth of $125 \%$ ETc, with averages of 164.2 and 160.5 $\mathrm{cm}$, respectively. According to Fancelli $\&$ Dourado Neto (2004), the plant, when in water deficit environment, can show decrease in its vegetative growth, and in some situations even total stoppage can occur.

Reduction of leaf area also influenced plant growth (Table 1). Generally, the smaller the photosynthetic area, the shorter the plant length, when this plant is in an environment with water availability close to the recommended for the crop (100\% ETc). However, the authors observed that, when water deficit is very high $(50 \% \mathrm{ETc})$, defoliation treatments showed results similar to control (100\% ETc), considering when $35 \%$ foliage was removed, plant length was about $7.3 \%$ longer than in plants which did not have their leaf blade removed.

Considering that plant development is influenced by photosynthetic process (Oliveira et al., 2014), according to results obtained in this study for plants under water deficit environment, plants may have acquired a photosynthetic compensatory mechanism, as reported by Iqbal et al. (2012), removing unproductive leaves (older leaves) at beginning of plant development, absorption balance is altered, which would increase photosynthetic activity in the rest of leaves, and consequently provide higher plants.

Generally, cob insertion was related directly to plant length; however, it was not observed in this study (Figure $1 \mathrm{~A}$ and 1B). Nevertheless, an increase of water depth resulted in increased cob insertion height in no-defoliation treatment, with an increase of $8.7 \%$ under the highest water depth $(125 \%$ $\mathrm{ETc}$ ) in relation to the lowest water depth $(50 \%$ ETc). Despite the initial length decrease in defoliation treatment, higher cob insertion height values were obtained with water depths of $125 \%$

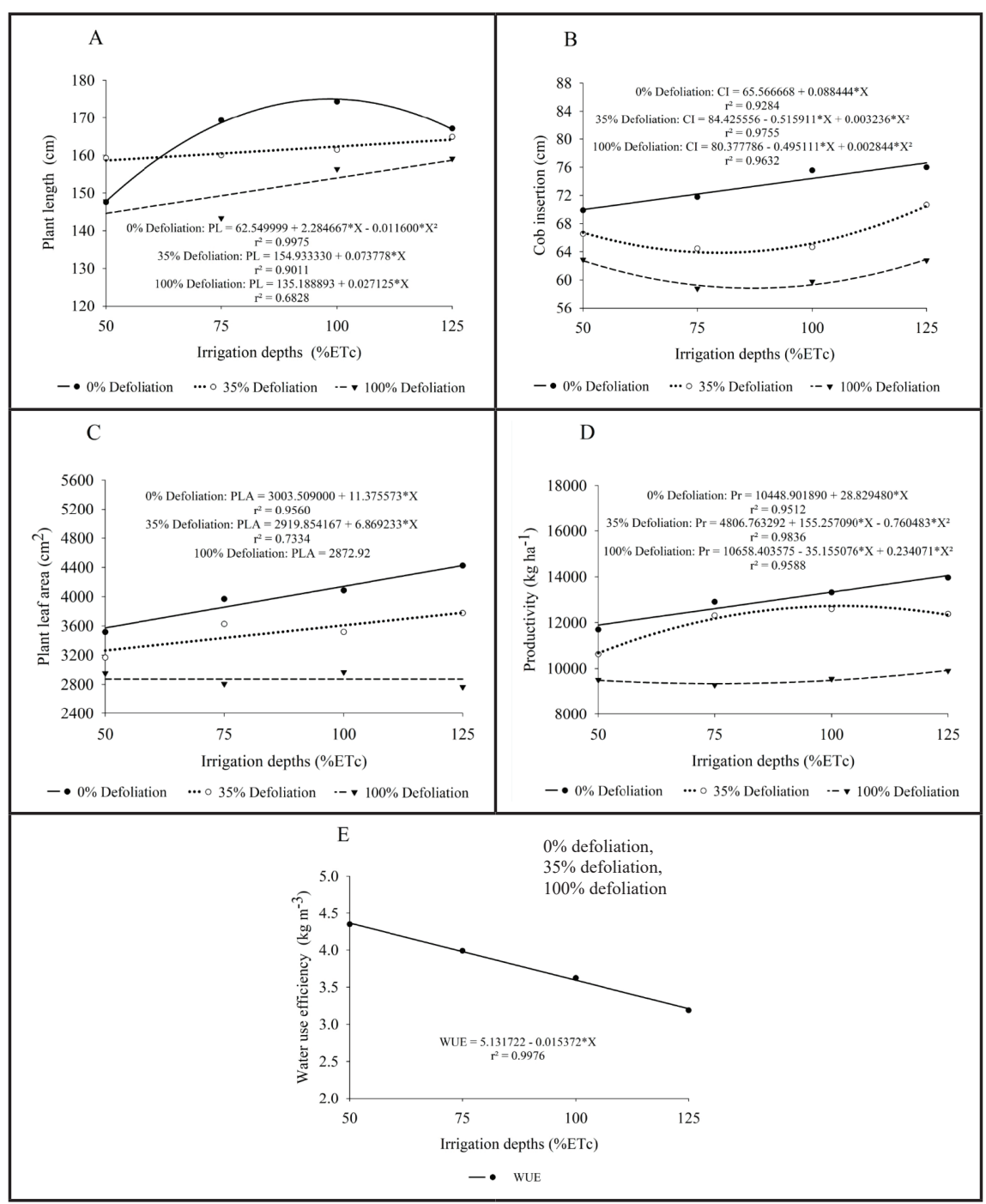

Figure 1. $\mathrm{PL}=$ plant length $(\mathrm{A}) ; \mathrm{CI}=\mathrm{cob}$ insertion $(\mathrm{B}) ; \mathrm{PLA}=$ plant leaf area $(\mathrm{C})$; $\mathrm{Pr}=$ productivity (D); WUE = and water use efficiency $(\mathrm{E})$ submitted to different irrigation depths. Chapadão do Sul, UFMS, 2016. 
ETc, showing average values of 70.50 and $62.9 \mathrm{~cm}$ for defoliation treatments, with removal of 35 and $100 \%$ of leaves, respectively (Figure 1B). Overall, no defoliation at the beginning stages of the plant resulted in plants with higher cob insertion length values, regardless irrigation level applied (Table 1).

Sweet corn defoliation at early development stages resulted in reduction of leaf area, being more pronounced with $100 \%$ defoliation (Table 1). This can be associated to a low vegetative plasticity of the crop, reduced prolificacy and limited effective capacity to fill empty spaces between plants (Sangoi et al., 2014). However, as water availability increased, the authors observed an increase in leaf area remaining at the end of the cycle, except for $100 \%$ defoliation treatment (Figure 1C). According to Oliveira et al. (2014), this reduction in leaf area in water deficit environments results from stomatal closing, since plant activates this mechanism in order to reduce water losses for atmosphere, which affects several plant physiological processes.

The authors observed that leaf injuries which occurred at early development stages impacted productivity, being higher yields observed when no defoliation was verified, regardless water depth applied (Table 1). When defoliation up to $35 \%$ of leaf area occurred, average productivity was statistically the same as noticed in no defoliation treatment under water depth with replacement up to $100 \%$ ETc; however, the larger the leaf area removed, the lower the productivity index obtained. According to Manfron et al. (2003), crop yield will be higher, the faster the plant reaches maximum leaf area index and the longer leaf area remains active, considering that total photosynthesis is influenced by leaf area.

An increase in water depth applied to crop resulted in higher productivity values, except for the treatment with up to $35 \%$ leaf area removal, in which this increase was not linear (Figure 1D), reaching maximum productivity of $12.73 \mathrm{t} \mathrm{ha}^{-1}$ using a water depth of $102 \% \mathrm{ETc}$, and in 0 and $100 \%$ leaf area removal treatments, highest productivities were noticed, under water

Table 1. $\mathrm{PL}=$ average values of plant length; $\mathrm{CI}=$ cob insertion; $\mathrm{PLA}=$ plant leaf area; $\mathrm{Pr}=$ productivity; WUE= water use efficiency according to each defoliation level. Chapadão do Sul, UFMS, 2016.

\begin{tabular}{|c|c|c|c|c|c|}
\hline \multirow{2}{*}{ Variable } & \multirow{2}{*}{$\begin{array}{l}\text { Defoliation } \\
\text { levels (\%) }\end{array}$} & \multicolumn{4}{|c|}{ Water depths (\% ETc) } \\
\hline & & 50 & 75 & 100 & 125 \\
\hline \multirow{3}{*}{ PL (cm) } & 0 & $147.56 \mathrm{~b}$ & $169.33 \mathrm{a}$ & $174.33 \mathrm{a}$ & $167.11 \mathrm{a}$ \\
\hline & 35 & $159.22 \mathrm{a}$ & $160.00 \mathrm{~b}$ & $161.44 \mathrm{~b}$ & $164.89 \mathrm{a}$ \\
\hline & 100 & $147.78 \mathrm{~b}$ & $143.33 \mathrm{c}$ & $156.33 \mathrm{~b}$ & $159.11 \mathrm{~b}$ \\
\hline \multirow{3}{*}{$\mathrm{CI}(\mathrm{cm})$} & 0 & $69.89 \mathrm{a}$ & $71.78 \mathrm{a}$ & $75.56 \mathrm{a}$ & $75.99 \mathrm{a}$ \\
\hline & 35 & $66.54 \mathrm{~b}$ & $64.46 \mathrm{~b}$ & $64.67 \mathrm{~b}$ & $70.67 \mathrm{~b}$ \\
\hline & 100 & $62.89 \mathrm{c}$ & $58.78 \mathrm{c}$ & $59.78 \mathrm{c}$ & $62.78 \mathrm{c}$ \\
\hline \multirow{3}{*}{$\operatorname{PLA}\left(\mathrm{cm}^{2}\right)$} & 0 & $3516.21 \mathrm{a}$ & $3968.29 \mathrm{a}$ & $4086.07 \mathrm{a}$ & $4424.92 \mathrm{a}$ \\
\hline & 35 & $3166.73 b$ & $3625.07 \mathrm{~b}$ & $3516.48 \mathrm{~b}$ & $3775.37 \mathrm{~b}$ \\
\hline & 100 & $2952.23 \mathrm{c}$ & $2807.11 \mathrm{c}$ & $2967.71 \mathrm{c}$ & $2764.64 \mathrm{c}$ \\
\hline \multirow{3}{*}{$\operatorname{Pr}\left(\mathrm{t} \mathrm{ha}^{-1}\right)$} & 0 & $11.70 \mathrm{a}$ & $12.90 \mathrm{a}$ & $13.32 \mathrm{a}$ & $13.96 \mathrm{a}$ \\
\hline & 35 & $10.62 \mathrm{ab}$ & $12.31 \mathrm{a}$ & $12.59 \mathrm{a}$ & $12.38 \mathrm{~b}$ \\
\hline & 100 & $9.51 \mathrm{~b}$ & $9.28 \mathrm{~b}$ & $9.54 \mathrm{~b}$ & $9.90 \mathrm{c}$ \\
\hline \multirow{3}{*}{$\begin{array}{l}\text { WUE (kg } \\
\left.\mathrm{m}^{-3}\right)\end{array}$} & 0 & \multicolumn{4}{|c|}{$4.25 \mathrm{a}$} \\
\hline & 35 & \multicolumn{4}{|c|}{$3.93 \mathrm{~b}$} \\
\hline & 100 & \multicolumn{4}{|c|}{$3.16 \mathrm{c}$} \\
\hline
\end{tabular}

Averages followed by different lowercase letters in the column differ from each other by the Tukey test $(\mathrm{p}<0.05)$.

depth of $125 \%$ ETc, with averages of 14.05 and $9.92 \mathrm{t} \mathrm{ha}^{-1}$, respectively.

The results obtained in the present study can be related to water conditions during critical period of crop, which, according to Bergamaschi et al. (2004), is from bolting to the beginning of grain filling; in this phenological stage maize is sensitive to water deficit. This sensitivity can be observed in physiological processes related to zygote formation and the beginning of grain filling, and in high transpiration which occurs during this period.

Comparing the water depth which provided the higher productivity for $35 \%$ defoliation $(102 \%$ ETc $)$ with the water depth of $100 \%$ ETc, a difference of only $5 \%$ in productivity was noticed. These results allow inferring that irrigation use probably caused a stimulating effect on the regeneration of leaf area of the early defoliated plants, direct or indirectly, confirming the hypothesis which originated this study. Nevertheless, when plants are moderately defoliated, this regeneration is better observed; because, despite an increase in productivity is observed if drastic defoliation occurs, with an increase of water depth (around 5.9\% from the lowest to the highest), this value is almost insignificant, if extra amount of water applied is compared.

Generally, higher values for EUA were observed where no reduction in leaf area of sweet corn was verified, being these values reduced as an increase of plant injury level was observed (Table 1). Increase in water availability for plants provided linear reduction in EUA, considering that better results were found using water depth with replacement of $50 \% \mathrm{ETc}$, with values of $4.36 \mathrm{~kg} \mathrm{~m}^{-3}$ (Figure 1E).

Concept of water use efficiency is quite relative, taking into account that higher efficiency does not mean higher productivity (Oliveira et al., 2011). This fact can be observed comparing productivity data (Figure 1D) and EUA (Figure 1E). Thus, higher EUA would represent less impact on the environment and would reduce production costs, considering economy of water or economy in the matrix of energy.

The authors concluded that irrigation 
use represents positive influence concerning recovery from damages caused by sweet corn defoliation at early stages of development, considering that success in irrigation management, as a strategy to reduce losses caused by defoliation, depends on leaf area lost and water depth applied.

\section{ACKNOWLEDGEMENTS}

To CAPES for giving the scholarship, Syngenta Seeds Ltda for providing the seeds and Petroisa Irrigação, for providing the drip tape and other connectors.

\section{REFERENCES}

ALLEN, RG; PEREIRA, LS; RAES, D; SMITH, M. 1998. Crop evapotranspiration: guidelines for computing crop water requirements. Roma: FAO. 300p.

BERGAMASCHI, H; DALMAGO, GA; BERGONCI, JI; BIANCHI, CAM; MULLER, AG; COMIRAN, F; HECKLER, BMM. 2004. Distribuição hídrica no período crítico do milho e produção de grãos. Pesquisa Agropecuária Brasileira 39: 831-839.

BERNARDO, S; SOARES, AA; MANTOVANI, EC. 2008. Manual de Irrigação. 8. ed. Viçosa:
Editora UFV. 625p.

EMBRAPA - Empresa Brasileira de Pesquisa Agropecuária. 2013. Sistema Brasileiro de Classificação de Solos. 3.ed. Brasília: EMBRAPA, 353p.

FANCELLI, AL; DOURADO NETO, D 2004. Produção de milho. 2. ed. Guaíba: Agropecuária, 360p.

IQBAL, N; MASOOD, A; KHAN, NA. 2012. Analyzing the significance of defoliation in growth, photosynthetic compensation and source-sink relations. Photosynthetica 50: 161-170.

KWIATKOWSKI, A; CLEMENTE, E. 2007. Características do milho doce (Zea mays L.) para industrialização. Revista Brasileira de Tecnologia Agroindustrial 1: 93-103.

KARAM，D; PEREIRA FILHO， IA; MAGALHÃES, PC; PAES, C; SILVA, JAA; GAMA, JCM. 2010. Resposta de plantas de milho à simulação de danos mecânicos. Revista Brasileira de Milho e Sorgo 9: 201211.

KELLER, J; BLIESNER, RD. 1990. Sprinkle and trickle irrigation. New York: Van Nostrand Reinold. 652p.

MANFRON, PA; DOURADO-NETO, D; PEREIRA, AR; BONNECARRÉRE, RAG; MEDEIROS, SLP; PILAU, FG. 2003. Modelo do índice de área foliar da cultura do milho. Revista Brasileira de Agrometeorologia 11: 333-342.

MAGALHÃES, PC; DURÃES, FOM. 2006. Fisiologia da produção de milho. Sete Lagoas: EMBRAPA. 10p.

OLIVEIRA JÚNIOR, LFG; DELIZA, R;
BRESSAN-SMITH, R; PEREIRA, MG; CHIQUIERE, TB. 2006. Seleção de genótipos de milho mais promissores para o consumo in natura. Ciência e Tecnologia de Alimentos 26: $159-165$.

OLIVEIRA, DB; MELO, MRM; CARDOSO, JAE; LAMBERT, RA. 2014. Avaliação fisiológica do milho (Zea mays) sob diferentes lâminas de irrigação, no município de Itumbiara-GO. Enciclopédia Biosfera, 10: 585-591.

OLIVEIRA, EC; CARVALHO, JA; REZENDE, FC; FREITAS, WA. 2011. Viabilidade técnica e econômica da produção de ervilha (Pisum sativum $\mathrm{L}$.) cultivada sob diferentes lâminas de irrigação. Engenharia Agrícola 31: 324-333.

PEEL, MC; FINLAYSON, BL; Mc MAHON, TA. 2007. Updated world map of the KöppenGeiger climate classification. Hydrology and Earth System Sciences 11: 1633-1644.

RITCHIE, SW; HANWAY, JJ; BENSON, GO. 1993. How a corn plant develops. Ames: Iowa State University of Science and Technology, 26p.

SANGOI, L; VIEIRA, J; SCHENATTO, DE; GIORDANI, W; BONIATTI, CM; DALL'IGNA, L; SOUZA, CA; ZANELLA, EJ. 2014. Tolerância à desfolha de genótipos de milho em diferentes estádios fenológicos. Revista Brasileira de Milho e Sorgo 13: 300-311.

SOUZA, DMG; LOBATO, E. 2004. Cerrado Correção do Solo e Adubação. 2 ed. Brasília: EMBRAPA, 416p.

TAIZ, L; ZEIGER, E. 2013. Fisiologia vegetal. 5. ed. Porto Alegre: Artmed, $918 \mathrm{p}$ 